\title{
Ecological theory and values in the determination of conservation goals: examples from temperate regions of Germany, United States of America, and Chile
}

\author{
Teoría ecológica y valores en la definición de objetivos de conservación: ejemplos de \\ regiones templadas de Alemania, Estados Unidos de América y Chile
}

\author{
KURT JAX ${ }^{1,2} \&$ RICARDO ROZZI ${ }^{2}$ \\ ${ }^{1}$ UFZ Centre for Environmental Research Leipzig-Halle, Department of Conservation Biology, Permoserstr. 15, D-04318 \\ Leipzig, Germany; \\ e-mail: kurt.jax@ufz.de \\ ${ }^{2}$ Omora Ethnobotanical Park, Universidad de Magallanes, and Omora Foundation, Puerto Williams, Chile; \\ e-mail: ricardo.rozzi@umag.cl
}

\begin{abstract}
The definition of conservation goals is a complex task, which involves both ecological sciences and social values. A brief history of conservation strategies in Germany (protection of cultural landscapes), United States (wilderness ideal), and southern Chile (preservation paradigm and the more recent interest in ecotourism) illustrates a broad range of conservation goals. To encompass such an array of conservation dimensions and goals, the ecosystem approach adopted by the Conference of the Parties of the Convention on Biological Diversity represents a good approach. However, to become effective, this kind of approach requires clarifying and agreeing upon basic concepts, such as ecosystem. To serve that purpose, we present a scheme that considers the selected phenomena, internal relationship, and the component resolution to define an ecosystem. We conclude that: (1) conservation traditions encompass interests in the preservation of both natural and cultural heritages, which also appear as mutually dependent dimensions. Hence, nature and humans are brought together as much in the goals as in the processes of conservation. (2) In the context of current global change, it is impossible to completely "isolate" protected areas from direct or indirect human influences. In addition, the current view of nature points out that biota and ecosystems will change over time, even in protected areas. Hence, in order to preserve species or habitats it is not enough to isolate protected areas, but it often requires active management and conservation actions. The two former conclusions suggest the need to revise the conservation approach that has been undertaken in the southern region of Chile, because (a) local people have been systematically excluded from protected areas, and (b) these areas lack personnel and facilities to conduct appropriate conservation and/or management programs. (3) Our analyses of the views of nature and conservation goals in different regions and/or historical moments demonstrate that these involve not only scientific criteria, but also philosophical, political and broader cultural, social and economic dimensions. Hence, effective conservation requires a greater degree of interdisciplinary and interagency cooperation.
\end{abstract}

Key words: conservation, comparative approach, ecological theory, Chile, ecotourism, ecosystem management, Germany, images of nature, Magellan region, social values, Yellowstone.

\section{RESUMEN}

La definición de los objetivos de conservación es una tarea compleja que involucra tanto valores sociales como teorías ecológicas. Un breve análisis histórico de las estrategias de conservación en Alemania (protección de paisajes culturales), Estados Unidos (protección de áreas silvestres) y el sur de Chile (paradigma preservacionista y más recientemente ecoturismo) exhibe un amplio espectro de objetivos de conservación. Para abordar tal diversidad de objetivos y dimensiones de conservación, la aproximación de ecosistemas de la Conferencia de las Partes de la Convención de Biodiversidad representa una aproximación apropiada. Sin embargo, para que este tipo de aproximaciones sea efectivo se requiere clarificar y coincidir acerca de conceptos básicos, tales como el de ecosistema. Para facilitar este propósito, presentamos un esquema que considera los fenómenos seleccionados, las relaciones internas y grado de resolución de los componentes. Concluimos que: (1) las tradiciones de conservación demuestran un interés tanto por el patrimonio natural como cultural, dimensiones que además aparecen como mutuamente dependientes. Por lo tanto, la naturaleza y los seres humanos se reúnen tanto en los objetos como en los procesos que conciernen a 
la conservación. (2) En el contexto del cambio global actual es imposible aislar completamente las áreas protegidas de la influencia humana directa o indirecta. Además, la actual perspectiva dinámica de la naturaleza enfatiza que las biotas y los ecosistemas cambiarán, aun en las áreas protegidas. En consecuencia, para preservar especies o hábitats no es suficiente "aislar" áreas protegidas, sino que a menudo se requieren acciones de conservación y manejos activos. Las dos conclusiones anteriores sugieren revisar la aproximación para la conservación adoptada en el extremo sur de Chile, debido a que (a) la gente local ha sido excluida de las áreas protegidas y (b) en estas áreas el personal y la infraestructura son insuficientes para conducir programas de conservación y/o manejo adecuados. (3) Análisis de las visiones de la naturaleza y de los objetivos de conservación en diferentes regiones y/o momentos históricos demuestran que estos involucran no solo criterios científicos, sino también dimensiones filosóficas y políticas, en contextos culturales, sociales y económicos. Por lo tanto, una conservación efectiva requiere promover un mayor grado de cooperación interinstitucional e interdiciplinaria.

Palabras clave: Alemania, conservación, Chile, ecoturismo, Magallanes, manejo de ecosistemas, visiones de la naturaleza, teoría ecológica, valores sociales, Yellowstone.

\section{INTRODUCTION}

A significant number and diversity of people and institutions agree about the necessity of conservation today (Primack et al. 2001). However, in spite of this general agreement, defining conservation goals is a complex issue and there is much disagreement on the questions of what to conserve and, moreover, how should this be done. At the same time, current globalization and large-scale ecological, economic and social problems make it necessary to set precise goals for conservation actions (Figueroa \& Simonetti 2003).

Setting aside some areas and leaving them alone, protecting them by drawing lines or even fences around them is not enough (Pickett et al. 1997, Armesto et al. 1998, Bruner et al. 2001, Liu et al. 2001). First, environmental problems are no longer purely local or regional, but they have now an important global dimension (Chapin \& Sala 2001). For example, atmospheric changes induced by humans, such as the Antarctic ozone hole or global warming due to greenhouse gases, are problems that affect and concern the planet and society as a whole (Vitousek 1994). Even more the causes and consequences of those changes are often spatially uncoupled, they do not stop at national boundaries, and they may lead to sequels of hitherto unknown dimensions (Rozzi \& Feinsinger 2001).

A second reason to argue about the direction of conservation efforts is that it is becoming increasingly evident that conservation cannot be done against the people and/or by completely excluding them from protected areas, but only with them (Alcorn 1991, Shaxson 1991, Toulmin 1991, Rozzi et al. 2000). Lack of participation of local communities has been a major cause of failure in many conservation projects (Abu Sin 1991), and at the same time, the rights of indigenous people and the value of traditional ecological knowledge has gained increasing recognition (Mark 2001)1, especially after the 1992 Earth Summit (Jardin \& Kares 2000).

We argue that conservation questions cannot be delegated to science alone because they are also questions of values for at least three reasons: (1) humans are affected by conservation actions (Alcorn 1991, Armesto et al. 2001), (2) the role of humans within conservation must be discussed in the face of conflicting social interests (Jardin \& Kares 2000, Rozzi et al. 2000), and (3) conservation essentially concerns our moral attitudes towards human and non-human nature (Callicott \& Nelson 1998, Callicott 1999).

This paper analyzes the role of ecological science and social values in the definition of conservation goals and discusses the difficulties of this definition. In particular, we discuss why nature alone cannot provide unequivocal guidelines and how ecological theory can contribute to define conservation units and criteria. Going beyond the traditional role of ecology as a provider of empirical data and predictions, we emphasize the hitherto neglected heuristic role of ecological theory in clarifying conservation goals and connecting facts and values.

We provide a historical introduction on the origins of protected areas in two Northern Hemisphere temperate countries, Germany and the United States, as two contrasting models. Following, we examine conservation criteria and policies involved in the protected areas of

\footnotetext{
${ }^{1}$ MARK A (2001) Symposium: managing protected natural areas for conservation, ecotourism, and indigenous people. Journal of The Royal Society of New Zealand 31: 811-812
} 
the southernmost forests of the world, in the Magellan archipelago of Chile. We compare the Chilean case with the Northern Hemisphere cases, as well as with more recent conservation approaches involving zoning and regulation of human activities within protected areas. These examples display a wide range of possible conservation approaches and the values implied within them. Building on these experiences, we finally discuss a novel approach for defining conservation goals, derived from ecological theory and ecosystem management concepts, which may help clarify the goals and the interface between societal decisions and scientific knowledge.

\section{EXPERIENCES FROM THE NORTH: HISTORICAL AND RECENT CONSERVATION GOALS IN GERMANY AND THE UNITED STATES}

Conservation efforts and the establishment of the first protected areas started in both, Germany and the United States, in the $19^{\text {th }}$ century. However, the main emphasis of conservation and the kinds of areas that were protected differed strongly on the two sides of the north Atlantic (Table 1).

The first protected area in Germany, established during the $1830 \mathrm{~s}$, was the Drachenfels, a hill with an old castle ruin towering above the banks of the Rhine south of Bonn (Fig.1). The reason to protect it as a natural monument (Naturdenkmal) was the danger of a complete destruction of the castle and the mountain side pointing towards the Rhine by a quarry, which had already caused part of the old ruin to collapse. Later the area was greatly extended to include the surrounding hills in the nature protection area (Naturschutzgebiet) in Siebengebirge. Both the hills of the Siebengebirge and the Drachenfels ruin, however, had a high symbolic value in the context of romanticism and the search for national identity in Germany, which at that time was divided into many small more or less independent states.

The broader conservation movement in Germany was articulated and driven towards practical and political relevance most effectively by the musician Ernst Rudorff. Inspired by the traditions of romantic art and skilled in writing, Rudorff became the major spokesman of the new idea of conservation (Knaut 1990). This conservation idea started not as a movement to protect "wild" landscapes, but as "Heimatschutz" (Dominick 1992, Knaut 1993), which meant the protection of the home country or home landscape (the "Heimat"). This was essentially the protection of cultural landscapes, that is of landscapes molded by centuries of extensive and use practices.

"Heimatschutz" was an explicit reaction against the rise of industrialization and urbanization in Germany. It expressed the desire to secure what was conceived as the historical identity of the German nation, which during Rudorff's time already existed as a unified state, since 1871. Thus in its first decades, conservation was mainly Heimatschutz and the conservation of natural monuments, a word coined explicitly as a parallel to cultural monuments, meaning extraordinary singular features of nature like particular old trees or remarkable rock assemblages.

TABLE 1

The beginnings of nature conservation in Germany and the United States Comienzos de la conservación de la naturaleza en Alemania y Estados Unidos

\begin{tabular}{ccc}
\hline & Germany & USA \\
\hline First protected area & $\begin{array}{c}\text { 1830s: first natural monument } \\
\text { (Drachenfels) } \\
\text { Later extended to nature } \\
\text { conservation area } \\
\text { (Naturschutzgebiet } \\
\text { Siebengebirge) }\end{array}$ & $\begin{array}{c}\text { 1872: first national park } \\
\text { (Yellowstone) }\end{array}$ \\
$\begin{array}{c}\text { Main emphasis of early } \\
\text { conservation }\end{array}$ & $\begin{array}{c}\text { Cultural landscapes, } \\
\text { protection of resources } \\
\text { Role of humans }\end{array}$ & Wild landscapes, \\
& Equilibrium including humans & protection of resources \\
& Equilibrium excluding \\
(modern) humans
\end{tabular}




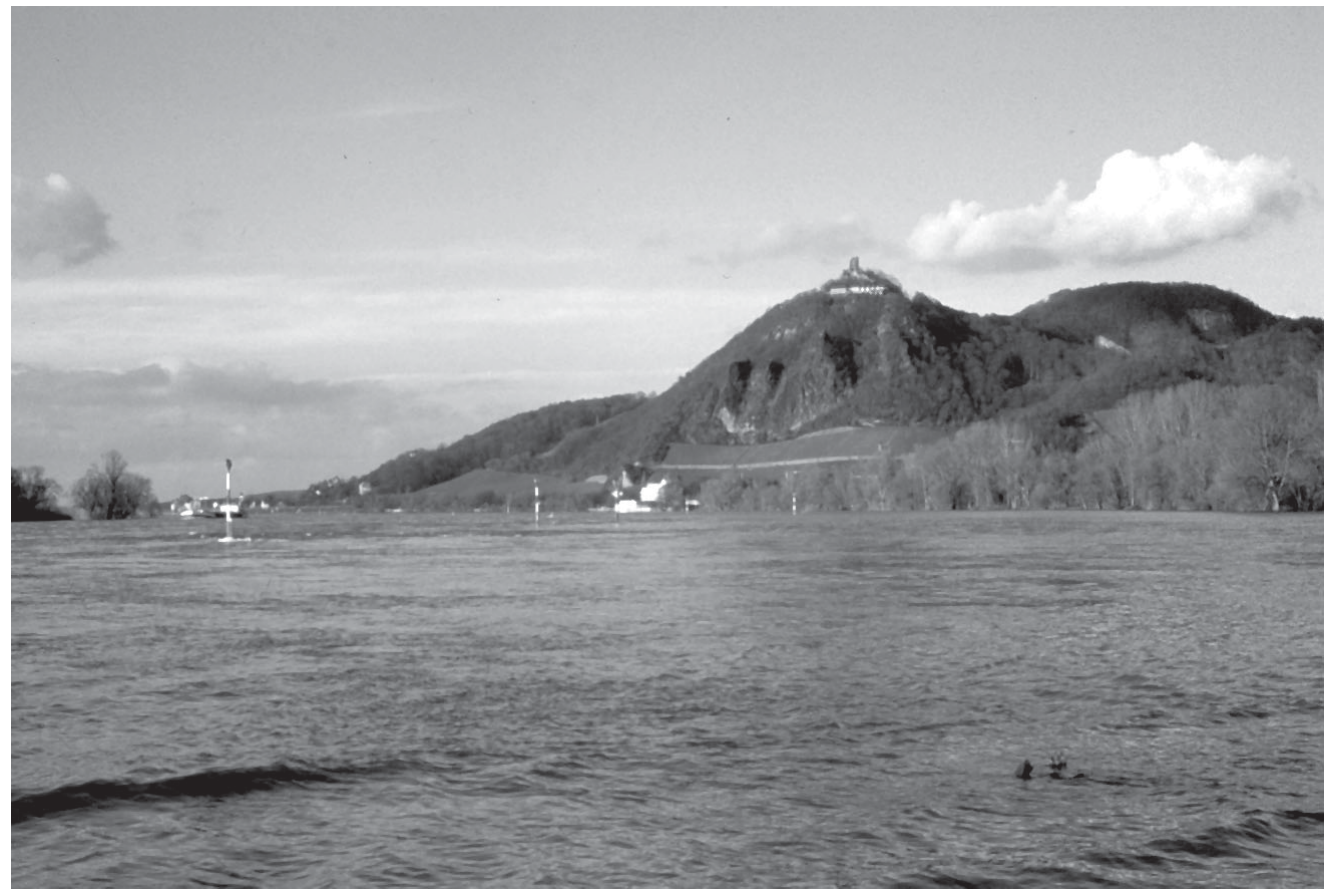

Fig. 1: The Drachenfels hills at the banks of the river Rhine, south of Bonn, Germany. The remains of the quarry that endangered the hill and the castle in the early $19^{\text {th }}$ century can still be seen. (Photo: Kurt Jax, early 2001).

Las colinas de Drachenfels en las riberas del río Rin al sur de Bonn, Alemania. Los remanentes de las canteras que amenazaron a la colina y al castillo a comienzos del siglo XIX. (Fotografía de K Jax, a comienzos del 2001).

An additional emphasis of early conservation in Germany was the protection of natural resources, e.g., birds (but only "useful" birds; see Berlepsch 1899) or game (Rozzi et al. 2001). Human beings were not excluded from conservation but, as major agents of the development of the rural landscapes, they were included in the idea of "Heimatschutz", however only as far as they dwelled in traditional, non-industrial lifestyles.

In contrast to the German model of "Heimatschutz", conservation efforts in the United States emphasized the protection of "wild", "untouched" landscapes, pursuing the "wilderness" ideal of Henry David Thoreau and John Muir (Nash 1982, Oelschlaeger 1991). The first park in the United States (state park at that time) was the Yosemite Valley in the Sierra Nevada of California, established in 1864 by the state of California. Later in 1890, Yosemite was declared a national park (Runte 1997).

The first national park in the United States was established in 1872, namely Yellowstone National Park, which also constitutes the first national park of the world. Moreover, Yellowstone can be considered the prototype of all national parks and has shaped this notion (Runte 1997, Sellars 1997). The area is situated in the northern Rocky Mountains of the United States, mostly in the state of Wyoming, and covers an area of almost 9,000 $\mathrm{km}^{2}$. It protected the wild landscape, which was perceived as not used and altered by humans. The main features which led to the establishment of this park were its magnificent landscapes, including many geothermal features - geysers and hot springs - and abundant wildlife, including attractive large mammals, such as grizzly bears (Ursus arctos) and elk (Cervus elaphus) (Fig. 2A and 2B).

Following the idea of wild landscapes, humans were explicitly excluded or at least considered irrelevant for the current appearance of the protected landscapes. This does not, however, imply that national parks were meant to exclude human visitors. The founding law of Yellowstone stated explicitly that the Park was created "for the benefit and enjoyment of the people." Until today the criteria of the International Union for Conservation of Nature and Natural Resources (IUCN 1994) for the establishment of national parks explicitly require restricted public access. Besides 

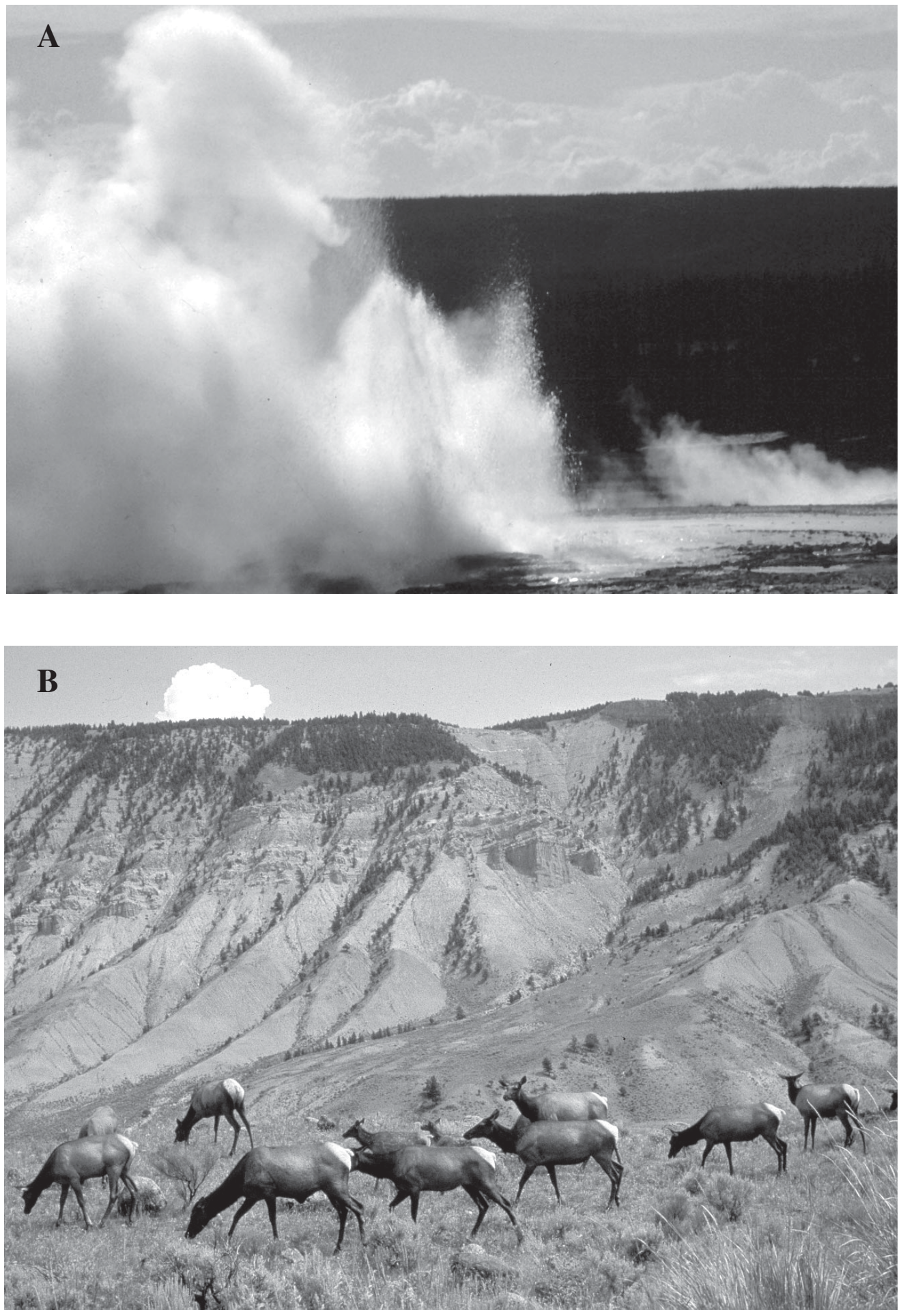

Fig. 2: The creation of the world's first national park (established 1872), Yellowstone National Park, was motivated by the fascination provoked by its magnificent landscapes, including geysers (A) and its wildlife, including large mammals like Cervus elaphus (B). (Photos: K Jax 1998).

La creación del primer parque nacional del mundo, Parque Nacional Yellowstone (establecido en 1872), fue motivada por la fascinación que provocaban sus magníficos paisajes (A) y su vida silvestre, que incluye grandes mamíferos como ciervo rojo (Cervus elaphus) (B). (Fotografías K Jax 1998). 
protecting wild nature, another emphasis of early American conservation was -as in Germany- the protection of natural resources, particularly forests, a current connected with the name of the forester Gifford Pinchot (see Norton 1991).

The American idea of preserving wild nature has become very popular and has been the inspiration of conservation systems in southern South America (see below). However, what is often forgotten is the fact that national parks were never meant to completely exclude people.

\section{SIMILARITIES BETWEEN GERMAN AND NORTH}

\section{AMERICAN MODELS OF CONSERVATION}

Evident differences place early conservation strategies in Germany and the United States at opposite ends of a gradient: culturally molded nature versus wild nature. At the same time, however, there are also important similarities between conservation approaches in both Northern Hemisphere regions, and those similarities have even become more apparent as knowledge about the conditions that prevailed in $19^{\text {th }}$ century North America increased.

As in Germany, the establishment of protected areas in the United States was a reaction to the growing impact of humans on the landscape. In North America, human impact was not as much industrialization and urbanization, but the extensive land use that reached the "untouched" western areas of the continent. In addition, the natural heritage of the wild and magnificent landscapes, protected in parks, was considered part of the identity of the American nation, as a substitute for the longer cultural heritage of the European nations (Nash 1982, Runte 1997).

During the $20^{\text {th }}$ century the early conservation aims were criticized in many respects (e.g., as being to narrow or too conservative), and were changed in that course. The German tradition of conserving cultural landscapes was soon extended to particular (rare) species of plants and animals, which often depended on these habitats, and later to the protection of wild landscapes. In 1970, almost 100 years after the establishment of Yellowstone National Park, the establishment of national parks began also in Germany with the creation of the Bavarian Woods National Park, the first German national park. Today, there are 13 national parks in Germany, with a few more in the stage of planning or negotiation. It is important to note, however, that to date most German parks do not fulfill the strict IUCN- criteria, which demand that at least $75 \%$ of the area should be completely free of human use. Especially in the last decade, the traditional approach of German conservation has been criticized as being too conservative and antiquated, turning nature into a museum with species. Further, many of those species would not occur in those protected areas without human influence, and they will not survive without the perpetuation of these old practices or their substitution by other forms of active management. This debate is still prevailing.

On the other hand, in the United States the notion of "untouched" nature has been seriously challenged (see Callicott \& Nelson 1998). Recent ecological, anthropological, and geological research has demonstrated that the landscapes of North America were not in a "pristine" state when Europeans arrived (Russell 1980, Callicott 1999). First, North American indigenous population was in the order of millions (Diamond 1999). Secondly, the notion of the American Indians as "noble savages" or "homo oecologicus" which had no significant impact on the natural setting has turned out to be an idealization. That simplified notion is as false as that of an almost "empty" country, waiting to be taken over by the white intruders (Mann 2002). The pendulum has swung back so far that some scholars see almost every landscape as influenced by land use practices of native Americans (e.g., Kay 1994; see Vale 1998 for a criticism). Similar doubts about the factual basis of the western wilderness idea have also been expressed for other parts of the Americas (e.g., GomezPompa \& Kaus 1992).

Under this perspective, Yellowstone or other American national parks would also be "cultural landscapes," if they are to be protected as "vignettes of primitive America," i.e., in the state which the first Europeans found them (as proposed in an influential paper by Leopold et al. 1963). In this case, humans, with their traditional land use practices would be included in American national parks as much as in traditional German "Naturschutzgebieten". However, both the American and the German ideal would exclude modern man as a valid actor, avoiding industrial and urban development in Europe, and non-indigenous European settlers in the United States.

In contemporary conservation strategies the seeming (and sometimes real) contradiction between the German and United States contrasting conservation philosophies 
becomes even less relevant. Several concepts have been developed aimed at reconciling conservation and human needs, which propose the design of protected areas including different zones subject to different intensity and type of human use. Hence, different conservation concepts - such as those of the contrasting German and United States traditions - would apply to different zones of a protected area.

The zoning criterion is an essential component of the Biosphere Reserve concept launched by UNESCO through its Man and Biosphere (MAB) program in the 1970s. Each biosphere reserve includes three distinct zones: (1) core zone, strictly dedicated to protect "wilderness," which involves complete exclusion of human activities (except regulated scientific research); (2) surrounding buffer areas, which are defined to permit or even foster traditional forms of land use which, in turn, may be essential to conserve the culturally founded diversity of habitats and species associated with those traditional practices; (3) transition areas, where productive and other economic activities and infrastructure are permitted (Jardin \& Kares 2000).

In southern South America, zoning criteria have been implemented as a mean to reduce user conflicts by the Argentinean administration of national parks in Patagonia (Martin \& Chehébar 2001, Salguero 2001). Each Argentinean national park includes five zones: (1) strict conservation areas, where human activity (except for scientific research) is forbidden; (2) extensive public use zones, where extensive uses such as scientific, educational, tourist and recreational are permitted; (3) intensive public use zones, which are relatively small areas where intensive tourism and recreation is allowed, including associated service infrastructure such as hotels, lodges, restaurants, camping facilities; (4) natural resource use zones, where sustainable productive activities and indigenous people residence are allowed; (5) special use areas, which are small areas for administration, services or human settlement not related to public use.

Strategies based on zoning criteria can provide a valuable bridge between opposite notions associated with the wilderness United States or the cultural landscape German conservation traditions. The zoning approach seems to us particularly suited for regions, such as southern South America, which maintain heterogeneous mosaics of landscapes regarding the degree of human influence. The extreme south of Chile, for example, includes a broad diversity of ecosystems that range from pristine (i.e., wild) to completely man-modified (i.e., cultural) landscapes (Rozzi 2002).

\section{CONSERVATION AND PROTECTED AREAS IN SOUTHERN CHILE}

Only four years after the creation of Yellowstone National Park in United States, the first Latin American protected area was established in Mexico. The creation of the Mexican Reserva Forestal Desierto de los Leones, was followed by the Reserva Perito Moreno in Argentina (1903), and the Reserva Forestal Malleco in Chile (1907) (Ormazábal 1988). Since then the number of national parks, state and private reserves has significantly increased in Chile (Armesto et al. 2001) and throughout Latin America (Primack et al. 2001). Today, the Chilean state maintains 92 protected areas, which includes 32 national parks, 47 reserves, and 13 national monuments (Table 2). The area protected by these 92 units represents $19 \%$ of the Chilean land surface, which almost triplicates the mean of $6.4 \%$ for South American countries (Armesto \& SmithRamírez 2001).

Among Chilean administrative regions, Magallanes exhibits an outstanding 7,079,285 ha of protected land, which represents more than 50 $\%$ of the region. National parks cover 4,732,785 ha, which represent $53 \%$ of the total area devoted to public national parks in Chile. Magellanic reserves comprise 2,346,189 ha, i.e., $42.6 \%$ of the area of reserves in the entire country. Therefore, Magallanes has the highest rank of protection in Chile, concentrating nearly $50 \%$ of the country's protected land. At the same time, such large amount of protected land emphasizes the importance of the Magellanic region as a reservoir of non-fragmented temperate ecosystems for Chile and the world.

In spite of the large proportion of protected land, current figures and conservation approaches in Magallanes present several problems. First, the country's distribution of protected areas is very biased toward the extreme south (Armesto et al. 1998). Administrative regions Eleventh (Aysén) and Twelfth (Magallanes), which extend between $44^{\circ}$ and $56^{\circ} \mathrm{S}$, include more than $80 \%$ of the Chilean protected land. Hence, large protected areas in Magallanes should not hide the lack of protection in other critical regions of Chile.

A second problem arises from the scarcity of park personnel: less than 20 park rangers work 


\section{TABLE 2}

Protected areas in the southernmost Administrative Region of Chile, Magallanes. For each category the total numbers $(\mathrm{N})$ and total area in Chile are given in parenthesis. The extreme right column calculates the percentage that each Magellanic protected area represents relative to the entire country

Áreas protegidas en la Región Administrativa más austral de Chile: Magallanes. Para cada categoría de área protegida se indican en paréntesis el número total $(\mathrm{N})$ y el área total en Chile. La columna al extremo derecho calcula el porcentaje que representa la superficie de cada área protegida de Magallanes respecto al área total protegida en el país

\begin{tabular}{|c|c|c|c|c|}
\hline Category & Name & Province & $\begin{array}{c}\text { Area } \\
\text { (ha) }\end{array}$ & $\begin{array}{l}\text { Percentage relative } \\
\text { to total protected } \\
\text { area in Chile }(\%)\end{array}$ \\
\hline & Bernardo O'Higgins & Última Esperanza & $* 2,962,420$ & 33.2 \\
\hline National Park & Torres del Paine & Última Esperanza & 242,242 & 2.7 \\
\hline (total in Chile: & Pali Aike & Magallanes & 5,030 & 0.1 \\
\hline $\mathrm{N}=32$ & Cabo de Hornos & Antártica & 63,093 & 0.7 \\
\hline \multirow[t]{3}{*}{$8,912,724$ ha) } & Alberto d Agostini & Antártica & $1,460,000$ & 16.4 \\
\hline & Subtotal & & $4,732,785$ & 53.1 \\
\hline & Alacalufes & Última Esperanza & $2,313,875$ & 42.0 \\
\hline Reserve & Laguna Parrillar & Magallanes & 18,814 & 0.3 \\
\hline (Total in Chile: & Magallanes & Magallanes & 13,500 & 0.2 \\
\hline \multirow{2}{*}{$\begin{array}{c}\mathrm{N}=47 \\
5,503,499 \text { ha) }\end{array}$} & Subtotal & & $2,346,189$ & 42.6 \\
\hline & Cueva del Milodón & Última Esperanza & 189 & 1.1 \\
\hline National & Los Pingüinos & Magallanes & 97 & 0.5 \\
\hline Monument & Laguna de los Cisnes & Tierra del Fuego & 25 & 0.1 \\
\hline (Total in Chile: & Subtotal & & 311 & 1.8 \\
\hline \multicolumn{5}{|l|}{$\mathrm{N}=13 ; 17,669$ ha) } \\
\hline Total Magallanes & & & $7,079,285$ & 49.0 \\
\hline Total Chile & & & $14,433,892$ & 100.0 \\
\hline
\end{tabular}

* This figure corresponds to the area of the National Park Bernardo O'Higgins included in the Region of Magallanes. The total area of this national park is 3525901 ha, but 563481 ha are included in the Region of Aysen, north of Magallanes (data from Muñoz et al. 1996)

permanently in Magallanes. This yields a mean of one park-ranger per $3,540 \mathrm{~km}^{2}$. This is a common problem in Latin America, where a dramatic situation also occurs in the Brazilian Amazon, which has only 23 permanent park rangers for the whole basin, i.e., an average of one park ranger per $6,053 \mathrm{~km}^{2}$ of protected land (Primack et al. 2001). This situation contrasts with the United States, which has 4,002 permanent park rangers, that is an average of one park ranger per $82 \mathrm{~km}^{2}$. The majority of protected areas in Magallanes also lack proper infrastructure, such as navigation media that are indispensable in this archipelago region. This lack of transport and personnel determines that not a single park-ranger works in the diverse habitats included in the 1,460,000 ha of the National Park de Agostini - the second largest of Chile. Therefore, most protected land in Magallanes, as is the case in other regions of Latin America, would fall within the label of "paper parks" (Rozzi \& Silander unpublished results). In fact, Magellanic national parks do not fulfill the requirements and the criteria of IUCN (1994) for this category of protected areas.

A third problem in the Magellanic region arises from the almost complete disregard for local people living close to protected areas, and in some cases indigenous residents have been displaced from their land (Rozzi et al. 2000, Rozzi 2002). The United States preservationist paradigm, sketched above, has had a strong influence on the conservation approach in the extreme south of Chile. The debate about the influence that pre-Columbian cultures had on their local ecosystems and regional landscapes, and the integration of indigenous people into conservation areas is as intense and controversial in South-America as in North America. This discussion involves two extreme positions: (1) one that idealizes aboriginal people as living in harmony with nature; and (2) another that considers native people as threats that should be removed from "pristine" or "natural" landscapes. Both are misleading oversimplifications (Alcorn 
1994). Regarding the first position, it would be interesting to evaluate the work done in southern Chile by the German missioner and anthropologist Martin Gusinde, who was deeply concerned about the future of the Fuegian Indians. In his monumental ethnographic work, Gusinde describes in detail several concepts and practices of traditional ecological knowledge of Kaweskar, Yahgan, and Selknam, indigenous people at the austral extreme of South America (see Gusinde 1946, 1961). Regarding the second position, it follows a preservationist approach identified with John Muir (see Norton 1991), which has been strongly influential for conservation designs in Latin America during the last 130 years (Rozzi et al. 2001). In southern Chile, indigenous populations have been excluded from national parks. For example, the national parks of Chiloé, Bernardo O'Higgins, and Cape Horn have respectively excluded Huilliche, Kaweskar, and Yahgan communities. Interestingly, today the general trend of abandonment and human exclusion in protected areas of southern Chile is changing due not only to conceptual changes about the role of humans as ecosystem components (McDonnell \& Pickett 1993, Rozzi et al. 1994), but also to a growing interest in ecotourism.

Ecotourism is promoting a shift, which instead of emphasizing a preservationist approach, underlines the statement "parks are created for the benefit and enjoyment of the people," asserted in the founding law of Yellowstone National Park. In the extreme south of Chile, this statement (which is closer to the United States conservation tradition identified with Gifford Pinchot, see Norton 1991), is acquiring a prevalent role today. This shift toward ecotourist activities requires, however, careful examination in order to achieve a sustainable compatibility between conservation and human needs or benefits (di Castri \& Balaji 2002, Figueroa et al. 2003).

Between Yellowstone National Park and the Magellan national parks, in particular Torres del Paine National Park, some remarkable similarities exist. In the Magellan Region, Torres del Paine National Park constitutes an area that, like Yellowstone, possesses marvelous landscapes (including glaciers and mountain peaks), and attractive megafauna (including species like rheas, Pterocnemia pennata, and guanacos, Lama guanicoe) (Fig. 3A and 3B). Also, like Yellowstone, Torres del Paine is visited by a large number of tourists (Fig. 4). Although the number of visitors to Torres del Paine (43,624 in 1995) ranks two orders of magnitude below Yellowstone (more than 3 million in 1995), for
Chile it holds the largest number of foreign visitors and it has a substantial impact on the development of the nearby city of Puerto Natales (Villarroel 1996). Of the visitors to Torres del Paine, $62 \%$ are from overseas, coming from Europe $(37 \%)$, North America $(15 \%)$, and Oceania (10\%) (Ferrer 2001).

Torres del Paine National Park was created in 1959, and was designated as a Biosphere Reserve in 1978. Like Yellowstone National Park, the Torres del Paine landscape shows signs of human influence. The austral landscape exhibits the marks left mainly by European colonists that arrived to Magallanes at the beginning of the $20^{\text {th }}$ century (Dollenz 1991). Before the Chilean government acquired the park, it belonged to German ranchers who burned large expanses of forests to increase pasture area, which was later overgrazed (see Martinic 1984). Therefore, in spite of the goal to protect pristine or "wild" areas, the imprints of both indigenous and European settlers, are present even in the remote austral regions of the American continent.

Within this context ecotourism poses complex puzzles to conservation biology. On the one hand, it seems to favor a larger integration between society and protected areas. On the other hand, with current deficiencies in the planning and regulation of ecotourism within parks, such as Torres del Paine, undesirable environmental impacts may follow (Villarroel 1996, Massardo et al. 2001). Hence, a close collaboration among government offices, tourism agencies, and academic institutions is required for the planning of protected areas, and defining their conservation goals.

\section{HUMAN VALUES, SCIENCE, AND THE DETERMINATION OF CONSERVATION GOALS}

The short overview of conservation strategies in Germany (protection of cultural landscapes), the United States (wilderness ideal), and southern Chile (preservation paradigm, and the more recent interest in ecotourism as a potentially sustainable economic activity) illustrates the broad spectrum of conservation goals and the different role of humans within conservation. Consequently, it is not always clear what exactly should be protected within reserves or national parks. However, with increasing human pressure on nature, especially in a period of rapidly growing global economy, and an increasing probability of human-induced global changes, the necessity for a conscious decision about conservation aims and measures 
(A)

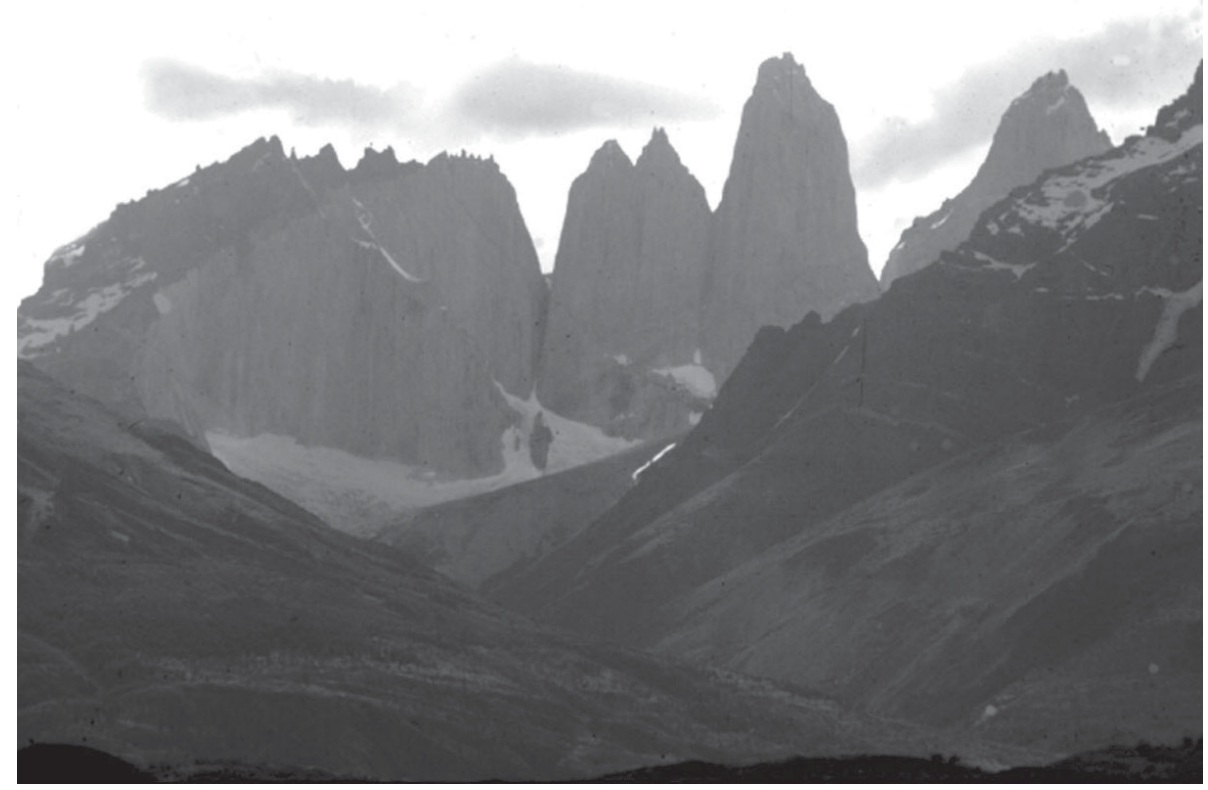

(B)

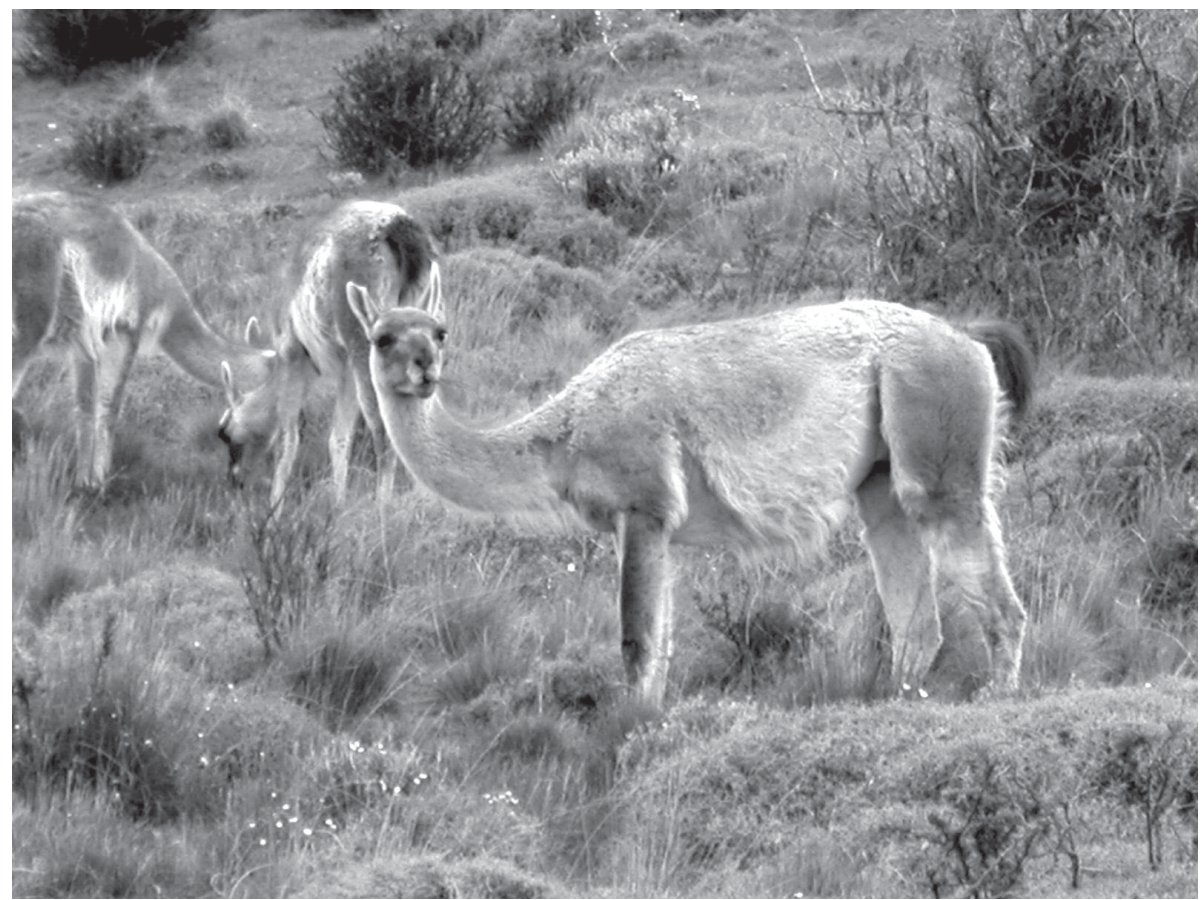

Fig. 3: Torres del Paine National Park was created in 1959, and declared a Biosphere Reserve in 1978. The criteria for the creation of Torres del Paine National Park follow closely those of Yellowstone National Park, that is, magnificent landscapes (particularly the Paine Towers [A]), and the abundant wildlife megafauna, which includes the guanaco (Lama guanicoe) [B]. Notice the analogy between Fig. 2 and 3. (Photos by Orlando Dollenz [A], and Ricardo Rozzi [B]).

El Parque Nacional Torres del Paine fue creado en 1959, y se declaró Reserva de la Biosfera en 1978. Los criterios para la creación del parque Torres del Paine son muy similares a aquellos que motivaron la creación del Parque Nacional Yellowstone: sus majestuosos paisajes (particularmente los Cuernos del Paine [A]), y la abundante presencia de megafauna y vida silvestre, que incluye al guanaco (Lama guanicoe) [B]. Nótese la analogía entre las Fig. 2 y 3 (Fotografías de Orlando Dollenz [A] y Ricardo Rozzi [B]). 


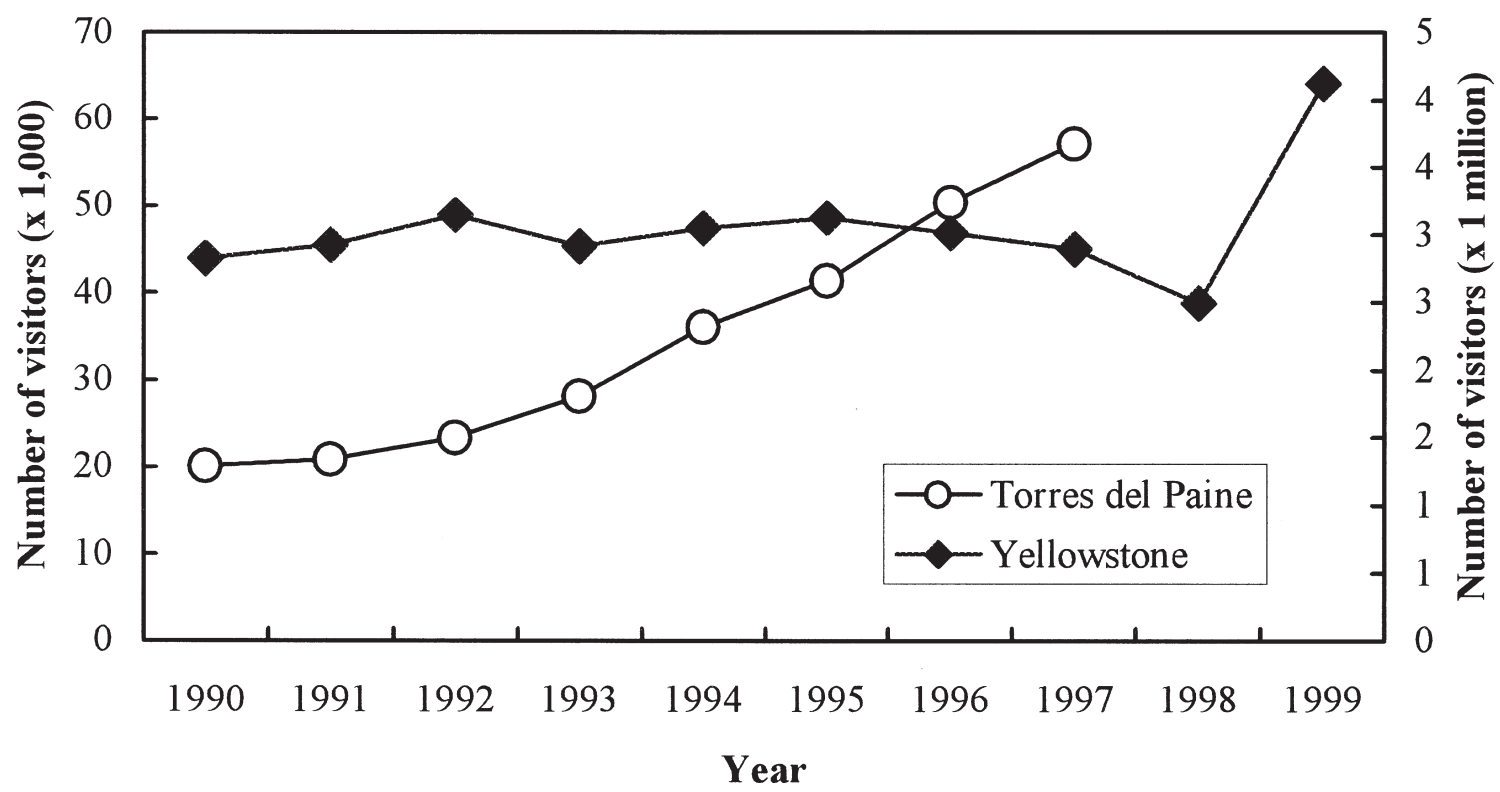

Fig. 4: Number of visitors to the national parks Yellowstone and Torres del Paine in the 1990s. Notice that the scales are visitors x1,000 for Torres del Paine, and visitors x1,000,000 for Yellowstone (Data from the administrative offices of CONAF, and Yellowstone National Park).

Número de visitantes a los parques nacionales de Yellowstone y Torres del Paine en 1990. Nótese que las escalas son de visitantes x1.000 para Torres del Paine, en cambio visitantes x1.000.000 para Yellowstone (datos de las oficinas administrativas de CONAF y Yellowstone National Park).

becomes greater. Confronted with this scenario, and a broad range of conservation goals: what should we protect? What roles should humans play in this context? Where can we find guidelines? What is the role of science?

Answering these questions requires to systematically integrate multiple aspects that influence any conservation strategy, aspects that hitherto have in part been developed independently from each other (Jentsch et al. 2003). Such integration has not been achieved, and it challenges the prevailing trend of specialization that dominates science and other disciplines since the second half of the $20^{\text {th }}$ century (Rozzi et al. 1998). Hence, to interconnect diverse aspects of conservation, such as empirical data, ecological theory, human values and worldviews, represents an urgent and important task. At the same time, this task demands novel theoretical and practical approaches.

Values enter the determination of conservation goals in many different ways: in our images of nature (Ahl \& Allen 1996, Rozzi 1999, Rozzi 2003), in our economic values (Daly \& Townsend 1994, Daily 1997), in our political preferences (Norton 1991), in our moral attitudes towards human and non-human nature (Rolston 1990), and even in our decisions about what is important in science. However, values are often not explicit and remain hidden behind seemingly objective scientific facts or economic necessities.

The provision of empirical data is one of the basic tasks of ecological research within conservation. It is necessary to describe the current conditions of an area or - by means of e.g., paleoecological analyses - to restore its "original" or "natural" conditions, e.g., in terms of plant cover or animal life. However, criteria for selection of particular areas and their subsequent management are not purely based on scientific knowledge.

What kinds of data are collected and what kinds of questions are asked is already a matter involving value decisions. Although many people argue that for conservation purposes ecology should simply identify the "natural" condition, this task is far from a purely "objective" scientific enterprise. For example, the concept of what is natural plays a major role when deciding which role should humans play within protected "natural" areas. Both the German and American early conservationists wished to protect "natural" landscapes although their images of what is "natural" differed 
considerably. In addition, these concepts have changed during the following decades and they still have different meanings for different groups of people. Particularly difficult questions related directly to value decisions arise today with respect to alien plants and animals (invasive species) entering an area and spreading there. Should they be considered as "natural"?

Ecological theory is a third important and often neglected ingredient in the determination of conservation goals, which can serve two main purposes. First, ecological theory allows us to go beyond a purely static description of an area, by providing insights into the interactions between the elements of ecological systems, their dynamics, and the ways they might respond to external changes. Ideally, ecological theory should provide the means for predicting the development of ecological systems.

A second, much less considered role of ecological theory is its heuristic use in the formulation of research questions and conservation goals (Jax 2003). Ecological theory can help identify gaps in our knowledge and expose uncertainties. Even more important within conservation, ecology can help clarify our questions, forcing us to be more precise about the concepts we use. Although this remains a difficult task, ecological theory can also help distinguish between values and facts and promote their integration in the definition of conservation goals. We illustrate this point using one of the currently most discussed approaches to conservation, the strategy of ecosystem management.

\section{PRESERVING ECOSYSTEMS: THE SOLUTION TO} CURRENT CONSERVATION DILEMMAS?

Ecosystem management represents an increasingly popular strategy, which is compatible with a dynamic view of nature (Christensen et al. 1996). It recognizes ecosystems as permanently changing and, at the same time, promotes a multiple use perspective.

The management of whole ecosystems -in contrast to that of single "commodities"- seems to be an elegant solution to many conservation problems. By protecting the whole ecosystem, we avoid protecting only certain parts of an area at the cost of others. This approach, to our knowledge, was first applied systematically in Yellowstone National Park, starting in the late 1960s (Jax 2001, 2002b). During the 1990s the notion of ecosystem management experienced a rapid rise in North American environmental policy (Grumbine 1994, Christensen et al. 1996, Boyce \& Haney 1997, Jax 2002b).

In contrast to its beginnings, in which ecosystem management was mainly a particular way of dealing with complex natural settings, the notion has now been extended to an ambitious societal program (Jax 2002b). Although the ecosystem approach in the United States means very different things to different people (Yaffee 1999), some common ground is emerging. The ecosystem is used here as a cipher for the treatment of "the whole", a whole that also includes humans, their societies and resource use practices. Moreover, it emphasizes, interagency management and a focus on natural boundaries in contrast to administrative ones (Grumbine 1994, Carpenter 1995, Szaro et al. 1998). In this context, the ecosystem and ecosystem management concepts are becoming strongly value-laden, departing from the perspective of "value-neutral" science.

It is this ecosystem approach which is applied by the Convention on Biological Diversity (CBD). The Fifth Conference of the Parties of this convention, which took place in Nairobi in 2000, passed a resolution that recommended the "ecosystem approach" as a cross-cutting issue for the CBD and obliged all parties to implement this approach within their conservation policies (resolution COP V/6). Based on the so-called Malawi-Principles, the approach emphasizes the social dimensions of management and that societal choices have to be made. It also acknowledges the changing nature of ecological systems (Botkin 1990, Pickett \& Ostfeld 1995, Plachter 1996).

The ecosystem approach is considered a major tool for implementing the three basic goals of the CBD, namely biological conservation, sustainable use of natural resources, and equitable sharing of benefits (Smith \& Maltby 2001). However, the implementation of such an approach is far from simple. First of all, it is an illusion that we would really be able to grasp the whole. This is an epistemological problem (Pickett et al. 1994, Rozzi et al. 1998). To investigate anything in nature, we have to select and isolate a particular characteristic of interest, from which we mentally form the system which we then describe and analyze. This has direct consequences for the scientific perception of the ecosystem as the very object of the ecosystem approach. In spite of some "naive-realistic" attitudes, an ecosystem is not a natural entity that can be identified in nature without reference to particular interests and selection criteria (Jax 
et al. 1998). It is defined in a task-specific manner. Definitions of ecosystems are manifold (Jax 2002a), and those that are commonly accepted as embracing the many and contrasting meanings are, in consequence, very general, too general to provide clear criteria for defining the goals of ecosystem management.

To implement an effective approach to ecosystem management it is necessary to: (1) set a baseline, (2) define what an ecosystem is, and (3) to have criteria to decide when it is "destroyed" or deviates significantly form a baseline condition.

For example, the case of southern Chile might involve questions such as: are the subantarctic evergreen rainforest ecosystems characterized by a particular species composition or just by a particular physiognomy of plant and animal types? Has the invasion of the North American beaver (Castor canadensis) -which started in the late 1940s on Tierra del Fuego, Navarino island and other areas of the Cape Horn archipelago (Lizarralde \& Venegas 2001)- created new and more diverse ecosystems? Today, is Castor canadensis part of the "old ecosystem" or is it the destroyer of the "original ecosystems"? Will we say that an ecosystem has become "another" ecosystem if some native undergrowth species are lost (or replaced by alien species) or will the ecosystem only be "another" if also its physiognomy is changed?

The ways in which ecosystems are defined must be communicated in a clear manner. However, this is still frequently not done, generating difficulties at different levels. To serve this communication purpose, Jax and collaborators (Jax et al. 1998, Jax 2002a) have recently developed an approach to clarify and provide an unambiguous definition and specification of any ecological unit. To do this, statements are needed about: (1) whether the unit is bounded topographically or functionally, (2) which kind of relationships among the components are minimally required, (3) which phenomena (i.e., components and internal relations) are selected for the definition of the unit, and (4) what is the degree of resolution of the unit's components.

The first criterion represents an essential distinction. It describes an element (e.g., organism) either seen as a part of a unit by virtue of being in a particular spatial location or by virtue of being functionally (i.e., by interactions) related to other elements. For example, within the bounds of a Nothofagus forest on an austral island, are all species components of one ecosystem or are there several separate ecosystems characterized by specific functional connections within these topographical bounds?

The remaining criteria apply to both spatialy and functionaly bounded units. They can be seen as gradients, which can be assembled as three axes into a graphical scheme that allows visualizing the different definitions (Fig. 5). The axis of selected phenomena displays which and how many phenomena (kinds of objects and/or processes) are included in the definition of the ecosystem. The axis of internal relationship indicates the degree of intensity and specificity that internal relationships are required to have in order to call a unit an ecosystem, or even an intact ecosystem. In some definitions, for example, the requirements to call a system an ecosystem are such that interactions have to be very specific and lead to an equilibrium state, or that feedback-loops are present which lead to the self-regulation of the system (high internal relationships). In other definitions any interactions between the organisms (low internal relationships) are sufficient to call the system an ecosystem. The axis of component resolution describes to what degree the components of the ecosystem must be resolved, e.g., whether the system parts are considered at the species or just trophic levels. Based on the initials of the three axes (selected phenomena, internal relationship, component resolution) this scheme was named "SIC-scheme" (Jax 2002a). Fig. 5 displays this general scheme to illustrate some of the most common meaning of ecosystem in the context of ecosystem management.

These meanings vary according to the conservation aims. The most general definition is depicted by the ellipse "A." Here the ecosystem is preserved simply as a system of interacting natural objects. Indeed, the interactions themselves may be the focus of management (which can also mean to refrain from active management). The kinds (i.e., species) of organisms are not of special importance here (low component resolution), and the degree of required internal relationships might also vary. For example, particular feedbacks may be demanded within the system to call it an ecosystem, such as the criterion that most primary production must occur within the system itself. This kind of ecosystem may be useful for the management of wilderness areas, even in regions that have been strongly impacted by humans but where now "nature can take its course". This is an especially interesting concept for ecosystem management in central European countries, where completely "pristine" areas no longer exist. 


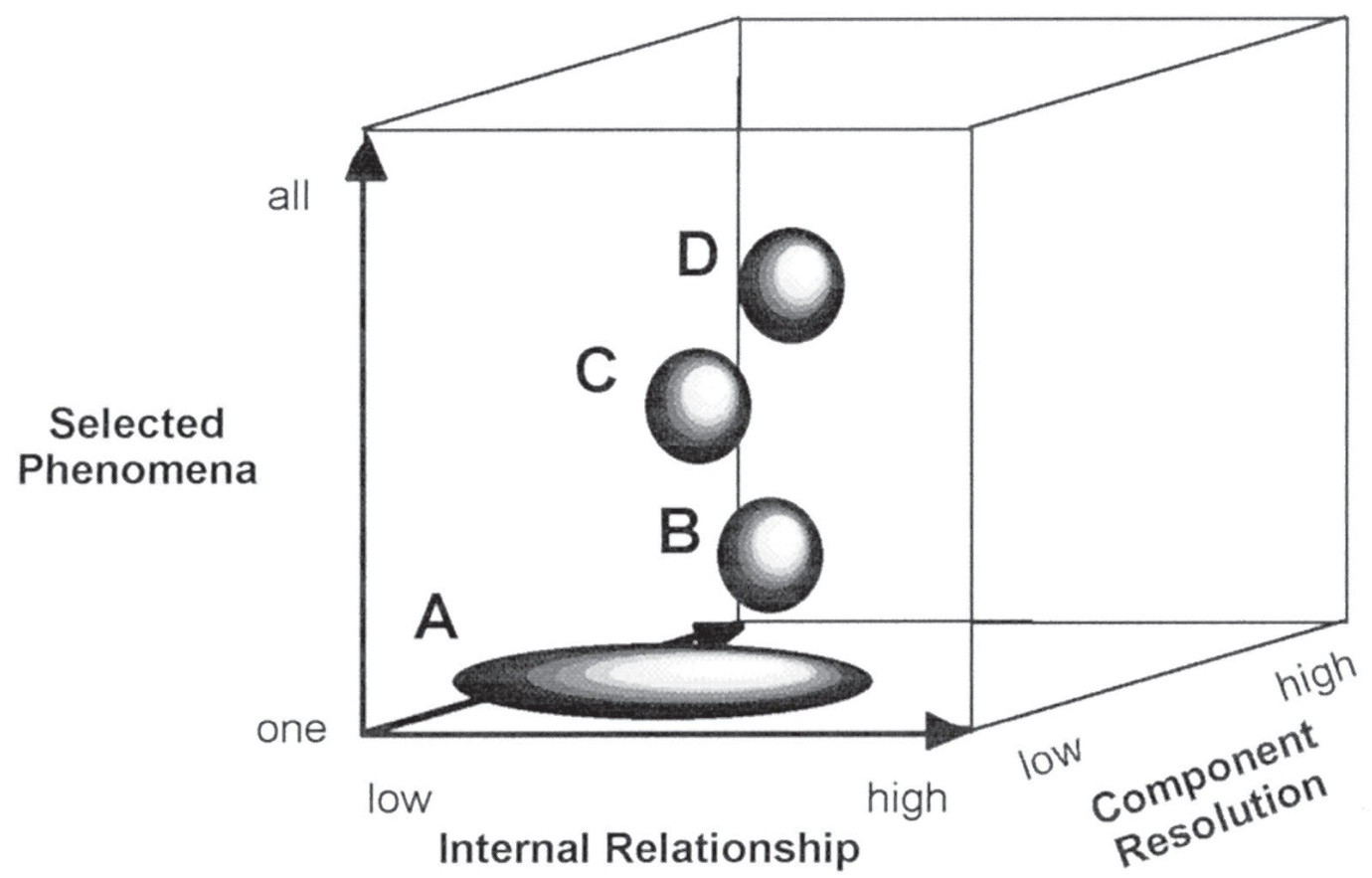

Fig. 5: Representation of different definitions of "ecosystem" that are applied in ecosystem management strategies (see text).

Representación de diversas definiciones de "ecosistema" utilizadas en las aproximaciones de manejo de ecosistemas (véase el texto).

Sphere "B" (Fig. 5) depicts another frequently applied definition of ecosystem, which focuses on particular interactions and processes. Here, the ecosystem is described by particular functional compartments, interacting in a manner that particular services -such as primary production, clean air or waters- are provided by the system. Component resolution is thus slightly higher than in type A, but still particular species are not of interest, only functional types. The degree of interaction is higher than in many other definitions because interactions, and particular feedbacks, between specific functional elements are essential for the definition. This kind of definition is sufficient when the aim of ecosystem management is to provide benefits for humans in the form of "ecosystem services" (Costanza et al. 1997).

Sphere "C" (Fig. 5) depicts a third type of ecosystem definition that demands a higher resolution in the three axes. For example, a Nothofagus forest ecosystem or a Sphagnum bog and the essential interactions that perpetuate such systems are to be protected. The aim is to protect a large ecosystem which is "typical" for the area, without the necessity that all constituent species have to be preserved in the long run, except for some conspicuous and dominant taxa such as Nothofagus trees and Sphagnum mosses. Particular types of taxa (indicator species, keystone species or "umbrella species"; see Simberloff 1998) are thus already part of the definition. This physiognomic- view of ecosystems is perhaps the most common one in the practice of conservation and resource management.

Finally, sphere "D" (Fig. 5) illustrates a concept of ecosystem defined by all species occurring in a setting. Interactions themselves are protected mostly for the sake of conserving the interacting components. These may be those species which are present in a protected area at a date $\mathrm{t}$ (e.g., the date at which the measures start) or -much more difficult to determine- all species which are considered as "typical" for a particular site. The aim is here to perpetuate all species, without fixing particular growth rates or dwelling places, abundances, or specific ratios between species. Everything, besides the species composition, is in a condition of waxing and waning, including local disturbances and recolonizations (within the system). This aim is formulated, for 
example, in some national parks and corresponds to the current strategy of ecosystem management in Yellowstone national park (Jax 2001).

\section{CONCLUDING REMARKS}

Based on the concise examination of conservation approaches that have taken place in temperate regions of Germany, United States, and Chile, followed by the analysis of conservation units based on the SIC-scheme, what can we learn for conservation in the austral Magellanic region?

First, conservation traditions encompass interests for the preservation of both natural and cultural heritages. Even more, these two dimensions are mutually dependent, as shown by the "natural areas" of Yellowstone and Torres del Paine, which have been molded in part by humans. Therefore, nature and humans are brought together in the object of conservation, as well as in the processes occurring in the protected units. Consequently, the dichotomies between nature and culture, and between protected areas and human presence become irrelevant.

Second, in the context of current global change it is impossible to completely isolate protected areas from human influences (Primack et al. 2001). Human impacts can arise as much from local populations (for example, firewood extraction) as from remote populations inhabiting a different hemisphere, as in the case of the austral ozone hole caused by the emissions of chemicals in Northern Hemisphere industrialized countries. Moreover, in the three temperate regions considered, humans as components of ecosystems may be a "keystone species." In addition, a dynamic view of nature -the "flux of nature"- points out that biotas and ecosystems will change over time, even within "protected areas." Hence, to preserve species or habitats it is not enough to "isolate" protected areas, but often it requires active management and conservation.

The two former conclusions invite us to revise the conservation approach undertaken in the extreme south of Chile, where local people have been excluded from protected areas, and where the National Forestry Service (CONAF, the organization responsible for these areas) has serious logistic and financial limitations to carry out conservation and/or management programs.

Third, our analyses demonstrate that conservation goals involve not only scientific criteria, but also philosophical, political and broader cultural, social and economic dimensions. Hence, interdisciplinary and interagency cooperation is urgently needed. None of these actors can see or understand the "whole" by themselves. Therefore, operational definitions of the units and goals of conservation need to be jointly defined. This process requires presenting explicitly the goals, methods and values involved in conservation or management of species and ecosystems.

Finally, we consider that the ecosystem approach to conservation, as currently conceptualized within the guidelines of the CBD, represents an extremely valuable tool. It allows integrating solid empirical research, sound ecological theory and human value dimensions. However, it is important to avoid the pitfalls that these approaches can have, when unproductive and improper mingling of facts and values involve a fuzziness of basic and practically relevant theoretical concepts, such as the ecosystem concept. These problems could undermine the usefulness of the ecosystem approach, concealing the issues really at stake. In this context, ecological theory, embedded in interdisciplinary work and social participatory proceses, represents an indispensable key element for determining conservation goals.

\section{ACKNOWLEDGEMENTS}

The authors thank Juan J. Armesto and an anonymous reviewer for valuable comments on the manuscript. The work that initially led to this paper has been kindly supported by travel grants of the Deutscher Akademischer Austauschdienst (DAAD) to Kurt Jax. Ricardo Rozzi acknowledges the support of the Department of Ecology \& Evolutionary Biology, University of Connecticut, and the Millenium Center for Advanced Studies in Ecology and Biodiversity (CMEB). This article is part of the BIOKONCHIL project (FKZ 01 LM 0208, German Ministry of Education and Research, BMBF), and the ongoing research and conservation activities conducted by the Omora Foundation and the Universidad de Magallanes, at the Omora Ethnobotanical Park, Puerto Williams, Chile.

\section{LITERATURE CITED}

ABU SIN ME (1991) Community-based sustainable development in central Butana, Sudan. In: Baxter 
PTW (ed) When the grass is gone: 152-161. The Scandinavian Institute of African Studies, Uppsala, Sweden.

AHL V \& TH ALLEN (1996) Hierarchy theory: a vision, vocabulary, and epistemology. Columbia University Press, New York, New York, USA. 206 pp.

ALCORN JB (1991) Ethics, economics and conservation. In: Oldfield ML \& JB Alcorn (eds) Biodiversity: culture, conservation and ecodevelopment: 317349. Westview Press, Boulder, Colorado, USA.

ARMESTO JJ \& C SMITH-RAMÍREZ (2001) Importancia de la distribución de las áreas protegidas: el caso del bosque chileno. In: Primack R, R Rozzi, P Feinsinger, R Dirzo \& F Massardo (eds) Elementos de conservación biológica: perspectivas Latinoamericanas: 454-456. Fondo de Cultura Económica, Ciudad de México, México.

ARMESTO JJ, C SMITH-RAMÍREZ \& R ROZZI (2001) A strategy for managing Chilean ecosystems for conservation and indigenous people. Journal of the Royal Society of New Zealand 31: 865-877.

ARMESTO JJ, R ROZZI, C SMITH-RAMÍREZ \& MTK ARROYO (1998) Effective conservation targets in South American temperate forests. Science 282: 1271-1272.

BERLEPSCH HV (1899) Der gesamte Vogelschutz, seine Begründung und Ausführung. Verlag Eugen Köhler, Gera, Germany. 89 pp.

BOTKIN DB (1990) Discordant harmonies. A new ecology for the 21th century. Oxford University Press, Oxford, United Kingdom. 241 pp.

BOYCE MS \& A HANEY (eds) (1997) Ecosystem management. Applications for sustainable forest and wildlife resources. Yale University Press, New Haven, Connecticut, USA. 361 pp.

BRUNER AG, RE GULLISON, RE RICE, G DA FONSECA (2001) Effectiveness of parks in protecting tropical biodiversity. Science 291: 125-128.

CALLICOTT B (1999) Beyond the land ethic: more essays in environmental philosophy. State University of New York Press, Albany, New York, USA. 427 pp.

CALLICOTT JB \& MP NELSON (1998) The great new wilderness debate. University of Georgia Press, Athens, Georgia, USA. 696 pp.

CARPENTER RA (1995) A consensus among ecologists for ecosystem management. Bulletin of the Ecological Society of America 76: 161-162.

CHAPIN T \& O SALA (eds) (2001) Future scenarios for biological diversity. Springer Verlag, Berlin, Germany. 392 pp.

CHRISTENSEN NL, AM BARTUSKA, SR CARPENTER, C D'ANTONIO, R FRANCIS, JF FRANKLIN, JA MACMAHON, RF NOSS, DJ PARSONS, CH PETERSON, MG TURNER \& RG WOODMANSEE (1996) The report of the Ecological Society of America committee on the scientific basis for ecosystem management. Ecological Applications 6: 665-691.

COSTANZA R, R D'ARGE, R DE GROOT, S FARBER, M GRASSO, B HANNON, K LIMBURG, S NAEEM, RV O'NEILL, J PARUELO, RG RASKIN, P SUTTON \& M VAN DEN BELT (1997) The value of the world's ecosystem services and natural capital. Nature 387: 253-260

DAILY G, ed. (1997) Nature's services: Societal Dependence on Natural Ecosystems. Island Press, Washington, District of Columbia, USA. 392 pp.

DALY HE, TOWNSEND KN (1994) Valuing the earth: economics, ecology, ethics. MIT Press, Cambrige, Massachusetts, USA. 384 pp.
DI CASTRI \& V BALAJI (2002) Tourism, biodiversity and information. Backhuys Publishers, Leiden, The Netherlands. $501 \mathrm{pp}$.

DIAMOND J (1999) Guns, germs, and steel: the fates of human societies. Norton \& Company, New York, New York, USA. 480 pp.

DOLLENZ O (1991) Recolonización de un coironal incendiado en el Parque Nacional Torres del Paine, Magallanes, Chile. Master Thesis, Facultad de Ciencias, Universidad de Chile, Santiago, Chile. 92 pp.

DOMINICK RHI (1992) The environmental movement in Germany. Prophets and pioneers 1871-1971. Indiana University Press, Bloomington, Indiana, USA. 290 pp.

FERRER M (2001) Turismo en Torres del Paine. Tesis de Maestría, Departamento de Geografía de la Universidad Autónoma de Madrid (UAM), Madrid, España. $154 \mathrm{pp}$.

FIGUEROA E \& J SIMONETTI (eds) (2003) Biodiversidad y globalización. Editorial Universitaria, Santiago, Chile. 327 pp.

FIGUEROA E, C BRAVO \& R ÁLVAREZ (2003) Biodiversidad y turismo: oportunidades para el desarrollo económico y la conservación en Chile. In: Figueroa E \& J Simonetti (eds) Biodiversidad y globalización: 285-323. Editorial Universitaria, Santiago, Chile.

GÓMEZ-POMPA A \& A AKAUS (1992) Taming the wilderness myth. Environmental policy and education are currently based on western beliefs about nature rather than on reality. BioScience 42: 271-279.

GRUMBINE RE (1994) What is ecosystem management? Conservation Biology 8: 27-38.

GUSINDE M (1946) Urmenschen im Feuerland. Paul Zsolnay Verlag, Berlin, Germany. 389 pp.

GUSINDE M (1961) The Yamana: the life and thought of the water nomads of Cape Horn. Volumes I-V, translated by F. Schutze. New Haven Press, New Haven, Connecticut, USA. 415 pp.

INTERNATIONAL UNION FOR CONSERVATION OF NATURE (IUCN) (1994) Guidelines for protected area management categories. IUCN, Gland, Switzerland. $261 \mathrm{pp}$

JARDIN M \& C KARES (2000) Solving the puzzle: the ecosystem approach and biosphere reserves. United Nations Educational, Scientific and Cultural Organization (UNESCO), Paris, France. 32 pp.

JAX K (2001) Naturbild, Ökologietheorie und Naturschutz: zur Geschichte des Ökosystemmanagements im Yellowstone-Nationalpark. Verhandlungen der Gesellschaft für Geschichte und Theorie der Biologie 7: $115-134$.

JAX K (2002a) Die Einheiten der Ökologie. Analyse, Methodenentwicklung und -anwendung in ökologie und Naturschutz. Peter Lang, Frankfurt, Germany. $249 \mathrm{pp}$

JAX K (2002b) Zur Transformation ökologischer Fachbegriffe beim Eingang in Verwaltungsnormen und Rechtstexte: das Beispiel des Ökosystembegriffs. In: Bobbert M, M Düwell \& K Jax (eds) Umwelt, Ethik \& Recht: 69-97. Francke-Verlag, Tübingen, Germany.

JAX K (2003) Wofür braucht der Naturschutz die wissenschaftliche Ökologie? Die Kontroversen um den Hudson River als Testfall. Natur und Landschaft 78: 93-99.

JAX K, CG JONES \& STA PICKETT (1998) The selfidentity of ecological units. Oikos 82: 253-264.

JENTSCH A, H WITTMER, K JAX, I RING \& K HENLE (2003) Biodiversity. Emerging issues for linking natural and social sciences. Gaia 12: 121-128. 
KAY CE (1994) Aboriginal overkill. The role of native Americans in structuring western ecosystems. Human Nature 5: 359-398.

KNAUT A (1990) Der Landschafts- und Naturschutzgedanke bei Ernst Rudorff. Natur und Landschaft 65: 114-118.

KNAUT A (1993) Zurück zur Natur! Die Wurzeln der Ökologiebewegung. Jahrbuch für Naturschutz und Landschaftspflege (Supplement)1: 1-480.

LEOPOLD AS, SA CAIN, CM COTTHAM, IM GABRIELSON \& TL KIMBALL (1963) Wildlife management in the national parks. Transactions of the North American Wildlife and Natural Resources Conference 28: 28-45

LIU J, M LINDERMAN, Z OUYANG, L AN, J YANG \& H ZHANG (2001) Ecological degredation in protected areas: the case of Wolong nature reserve for giant pandas. Science 292:98-101.

LIZARRALDE M \& C VENEGAS (2001) El castor: un ingeniero exótico en las tierras más australes del planeta. In: Primack R, R Rozzi, P Feinsinger, R Dirzo \& F Massardo (eds) Elementos de conservación biológica: perspectivas Latinoamericanas: 233 235. Fondo de Cultura Económica, Ciudad de México, México.

MANN C (2002) 1491. The Atlantic 289: 195-211.

MARTÍN C \& C CHEHÉBAR (2001) The national parks of Argentinian Patagonia -management policies for conservation, public use, rural settlements, and indigenous communities. Journal of The Royal Society of New Zealand 31: 845-864.

MARTINIC M (1984) Última esperanza en el tiempo. Ediciones Universidad de Magallanes, Punta Arenas, Chile. 289 pp.

MASSARDO F, O DOLLENZ \& R ROZZI (2001) Ecoturismo en el Cono Austral de América. In: Primack R, R Rozzi, P Feinsinger, R Dirzo \& F Massardo (eds) Elementos de conservación biológica: perspectivas Latinoamericanas: 303-305. Fondo de Cultura Económica, Ciudad de México, México.

MCDONNELL MJ \& STA PICKETT (eds) (1993) Human as components of ecosystems. Springer Verlag, New York, New York, USA. 364 pp.

MCKIRAHAN RD (1994) Philosophy before Socrates. Hackett Publishers, Indianapolis, Indiana, USA. $436 \mathrm{pp}$

MUÑOZ M, H NÚÑEZ \& J YÁÑEZ (eds) (1996) Libro rojo de los sitios prioritarios para la conservación de la biodiversidad biológica en Chile. Corporación Nacional Forestal, Santiago, Chile. 203 pp.

NASH R (1982) Wilderness and the American mind. Yale University Press, New Haven, Connecticut, USA. $425 \mathrm{pp}$.

NORTON BG (1991) Toward unity among environmentalists. Oxford University Press, New York, New York, USA. 287 pp.

OELSCHLAEGER M (1991) The idea of wilderness. Yale University Press, New Haven, Connecticut, USA. $477 \mathrm{pp}$.

ORMAZÁBAL C (1988) Sistemas nacionales de áreas protegidas en América Latina. Oficina Regional de la FAO (Food and Agriculture Organization of the United Nations) para América Latina y el Caribe, Santiago, Chile. 205 pp

PICKETT STA, J KOLASA \& CG JONES (1994) Ecological understanding: the nature of theory and the theory of nature. Academic Press, Orlando, Florida, USA. xiii + 206 pp.

PICKETT STA \& RS OSTFELD (1995) The shifting paradigm in ecology. In: Knight RL \& SF Bates (eds) A new century for natural resources management: 261-278. Island Press, Washington, District of Columbia, USA.

PICKETT STA, M SHACHAK, RS OSTFELD \& GE LIKENS (1997) Toward a comprehensive conservation theory. In: Pickett STA, RS Ostfeld, M Shachak \& GE Likens (eds) The ecological basis of conservation: heterogeneity, ecosystems, and biodiversity: 384-399. Chapman \& Hall, New York, New York, USA.

PLACHTER H (1996) Bedeutung und Schutz ökologischer Prozesse. Verhandlungen der Gesellschaft für Ökologie 26: 287-303.

PRIMACK R, R ROZZI, P FEINSINGER, R DIRZO \& F MASSARDO (2001) Elementos de conservación biológica: perspectivas Latinoamericanas. Fondo de Cultura Económica, Ciudad de México, México. $797 \mathrm{pp}$.

ROLSTON HI (1990) Biology and philosophy in Yellowstone. Biology and Philosophy 5: 241-258.

ROZZI R (1999) The reciprocal links between evolutionary-ecological sciences and environmental ethics. BioScience 49: 911-921.

ROZZI R (2002) Biological and cultural conservation in the archipelago forest ecosystems of southern Chile. Ph.D. Thesis, Department of Ecology and Evolutionary Biology, University of Connecticut, Storrs, Connecticut, USA. 359 pp

ROZZI R (2003) Biodiversity and social wellbeing in South America. Encyclopedia of Life Support Systems (EOLSS). UNESCO-EOLSS. http:// www.eolss.net

ROZZI R \& P FEINSINGER (2001) Desafíos para la conservación biológica en Latinoamérica. In: Primack R, R Rozzi, P Feinsinger, R Dirzo \& F Massardo (eds) Elementos de conservación biológica: perspectivas Latinoamericanas: 661-688. Fondo de Cultura Económica, Ciudad de México, México.

ROZZI R, JJ ARMESTO \& J FIGUEROA (1994) Biodiversidad y conservación de los bosques nativos de Chile: una aproximación jerárquica. Bosque 15: 55-64.

ROZZI R, E HARGROVE, JJ ARMESTO, STA PICKETT \& J SILANDER (1998) "Natural drift" as a postmodern metaphor. Revista Chilena de Historia Natural 71: 9-21.

ROZZI R, J SILANDER, JJ ARMESTO, P FEINSINGER \& F MASSARDO (2000) Three levels of integrating ecology with the conservation of South American temperate forests: the initiative of the Institute of Ecological Research Chiloé, Chile. Biodiversity and Conservation 9: 1199-1217.

ROZZI R, R PRIMACK, P FEINSINGER, R DIRZO \& F MASSARDO (2001) ¿Qué es la Conservación? In: Primack R, R Rozzi, P Feinsinger, R Dirzo \& F Massardo (eds) Elementos de conservación biológica: perspectivas Latinoamericanas: $35-58$. Fondo de Cultura Económica, Ciudad de México, México.

RUNTE A (1997) National parks. The American experience. University of Nebraska Press, Lincoln, Nebraska, USA. $335 \mathrm{pp}$.

RUSSELL HS (1980) Indian New England before the Mayflower. University Press of New England, Hanover, New Hampshire, USA. 284 pp.

SALGUERO J (2001) Integración social en los parques nacionales andino-patagónicos. In: Primack $\mathrm{R}, \mathrm{R}$ Rozzi, P Feinsinger, R Dirzo \& F Massardo (eds) Elementos de conservación biológica: perspectivas Latinoamericanas: 499-501. Fondo de Cultura Económica, Ciudad de México, México. 
SELLARS RW (1997) Preserving nature in the national parks. A history. Yale University Press, New Haven, Connecticut, USA. 380 pp.

SHAXSON TF (1991) National development policy and soil conservation programs. "Conservation for Sustainable Hillslope Farming", International Workshop Proceedings. FAO, Masera, Lesotho, South Africa.

SIMBERLOFF D (1998) Flagships, umbrellas, and keystones: is single-species management passé in the landscape era? Biological Conservation 83: 247-257.

SMITH RD \& E MALTBY (2001) Using the ecosystem approach to implement the CBD. A global synthesis report drawing lessons from three regional pathfinder workshops. UNESCO/MAB (http// :www.unesco.org/mab/docs/Report.pdf), Paris, France. 69 pp.

SZARO RC, WT SEXTON \& CR MALONE (1998) The emergence of ecosystem management as a tool for meeting people's needs and sustaining ecosystems. Landscape and Urban Planning 40: 1-7.

TOULMIN C (1991) Bridging the gap between top-down and bottom-up in natural resource management. In: Baxter PTW (ed) When the grass is gone:152-161. The Scandinavian Institute of African Studies, Uppsala, Sweden.

VALE TR (1998) The myth of the humanized landscape: an example from Yosemite National Park. Natural Areas Journal 18: 231-236.

VILLARROEL P (1996) El caso de Puerto Natales - Torres del Paine, XII Región: efecto del turismo en el desarrollo local. Ambiente y Desarrollo XII 4: 5864.

VITOUSEK PM (1994) Beyond global warming: ecology and global change. Ecology 75: 1861-1876.

YAFFEE SL (1999) Three faces of ecosystem management. Conservation Biology 13: 713-725.

Associate Editor: Juan Armesto

Received August 19, 2002; accepted November 21, 2003 